\title{
Atitudes Atuais de Anestesiologistas e Médicos em Especialização com Relação à Anestesia Venosa Total ${ }^{\star}$ Current Attitude of Anesthesiologists and Anesthesiology Residents Regarding Total Intravenous Anesthesia
}

\author{
Fernando Squeff Nora, TSA ${ }^{1}$, Marcos Aguzzoli, TSA², Getúlio Rodrigues de Oliveira Filho, TSA
}

\section{RESUMO}

Nora FS, Aguzzoli M, Oliveira Filho GR - Atitudes Atuais de Anestesiologistas e Médicos em Especialização com Relação à Anestesia Venosa Total.

JUSTIFICATIVA E OBJETIVOS: No passado, tempo, custos, informações, treinamento e avaliação da profundidade da anestesia limitavam a aceitação da anestesia venosa total (TIVA). O objetivo deste estudo foi determinar atitudes de anestesiologistas e médicos em especialização com relação à anestesia venosa total.

MÉTODO: Um questionário foi enviado a 150 anestesiologistas e 102 residentes. A concordância $(C)$ e discordância $(D)$ em cada item foram comparadas por testes $z$ (consenso, se $p<0,05$ ).

RESULTADOS: Houve 98 respostas. Os dados representaram números de respostas por categoria. A maioria dos participantes concordou que a qualidade do despertar estimula o uso de TIVA $(C / D=$ 86/8; $p<0,05)$; que o futuro reside no desenvolvimento de fármacos com rápido início de ação e pronta recuperação $(C / D=88 / 5$; $p<$ $0,05)$; que gostaria de utilizar TIVA com mais freqüência $(C / D=72 /$ 21; $p<0,05)$ e de saber mais sobre TIVA $(C / D=77 / 14 ; p<0,05)$. Não houve consenso sobre o nível de conhecimento para realizá-la, comparada com a anestesia inalatória $(C / D=48 / 47)$; a maioria não expressou preocupação com a consciência intra-operatória $(C / D$ = 20/77; $p<0,05$ ), mas concordou que a disponibilidade de monitores de consciência aumentaria a utilização de TIVA (C/D = 64/25; $p<0,05)$. Não houve consenso se a necessidade de bombas de infusão $(C / D=52 / 40)$ e custos $(C / D=52 / 39)$ limita o seu uso.

CONCLUSÕES: As atitudes com relação à TIVA foram predominantemente positivas. Não houve consenso sobre as contribuições do nível de conhecimento, dos dispositivos de infusão e dos custos para o uso de TIVA.

${ }^{*}$ Recebido dos (Received from) Hospitais Moinhos de Vento, Mãe de Deus de Porto Alegre e do CET/SBA Integrado de Anestesiologia da Secretaria de Estado da Saúde de Santa Catarina, Florianópolis, SC.

1. Presidente da Sociedade de Anestesiologia do Rio Grande do Sul.

2. Vice-Diretor Científico da Sociedade de Anestesiologia do Rio Grande do Sul.

3. Responsável do CET/SBA Integrado de Anestesiologia da SES-SC.

Apresentado (Submitted) em 26 de julho de 2005

Aceito (Accepted) para publicação em 25 de abril de 2006

Endereço para correspondência (Correspondence to):

Dr. Getúlio Rodrigues de Oliveira Filho

Rua Luiz Delfino, 111/902

88015-360 Florianópolis, SC

E-mail: grof@th.com.br

(c) Sociedade Brasileira de Anestesiologia, 2006.
Unitermos: METODOLOGIA CIENTÍFICA: pesquisa de opinião; TÉCNICAS ANESTÉSICAS, Geral: venosa.

\section{SUMMARY}

Nora FS, Aguzzoli M, Oliveira Filho GR - Current Attitude of Anesthesiologists and Anesthesiology Residents Regarding Total Intravenous Anesthesia.

BACKGROUND AND OBJECTIVES: In the past, time, cost, information, training, and the evaluation of the plane of anesthesia limited the acceptance of total intravenous anesthesia (TIVA). The objective of this study was to determine the attitude of anesthesiologists and other anesthesiology residents regarding total intravenous anesthesia.

METHODS: A questionnaire was sent to 150 anesthesiologists and 102 residents. The concordance $(C)$ and disaccord $(D)$ of each item were compared by $z$ tests (consensus if $p<0.05$ ).

RESULTS: There were 98 responses. The data represent the number of answers for each category. The majority of the participants agreed that the quality of the awakening stimulates the use of the TIVA $(C / D$ $=86 / 8 ; p<0.05)$; that the future depends on the development of drugs with a fast onset of action and immediate recovery $(C / D=88 / 5 ; p<$ $0.05)$; that they would like to use TIVA more often $(C / D=72 / 21 ; p$ $<0.05)$; and to have more information about TIVA $(C / D=77 / 14 ; p<$ 0.05). There was no agreement about the level of knowledge necessary to administer this technique when compared to inhalational anesthesia ( $C / D=48 / 47)$; the majority of those who answered the questionnaire did not express any concerns with intra-surgical consciousness $(C / D=20 / 77 ; p<0.05)$ but agreed that de availability of consciousness monitors would increase the use of TIVA $(C / D=$ 64/25; $p<0.05)$. There was no consensus whether the need for infusion pumps $(C / D=52 / 40)$ and costs $(C D=52 / 39)$ limit its use.

CONCLUSIONS: The attitude regarding TIVA was predominantly positive. There was no consensus on the influence of the level of knowledge, of the infusion pumps, and of the costs on the use of TIVA.

Key Words: ANESTHETIC TECHNIQUES, General: intravenous; SCIENTIFIC METHODOLOGY: survey.

\section{INTRODUÇÃO}

A anestesia balanceada, em geral relacionada com a utilização de fármacos inalatórios e venosos, dominou o cenário mundial entre as técnicas de administração de anestesia geral durante muitos anos ${ }^{1}$. Atualmente, a anestesia balanceada tem dividido espaço, entre as preferências dos anestesiologistas, com a anestesia venosa total (TIVA) ${ }^{2}$. Embora ainda pouco utilizada, a TIVA já é técnica de escoIha em alguns países europeus². 
Wright e Dundee ${ }^{3}$ publicaram um estudo realizado no Reino Unido avaliando atitudes frente à realização de TIVA, mais especificamente com relação à aceitação da técnica. As principais causas de insatisfação foram os dispositivos de infusão disponíveis, os custos, a ausência de agentes venosos adequados e seguros, a dificuldade de determinar o plano anestésico e a falta de informação e treinamento.

Modernamente pode-se citar, entre outras, duas mudanças que determinaram um incremento da TIVA, ou seja, a compreensão e o desenvolvimento de modelos farmacocinéticos para os novos fármacos venosos, que possibilitaram a sua utilização de forma contínua ${ }^{4} \mathrm{e} o$ advento dos monitores de consciência para uso perioperatório ${ }^{2,5,6}$.

Nora e col. ${ }^{7}$, por meio da utilização de pré e pós-teste aplicados em cursos de TIVA, identificaram alguns fatores responsáveis pela dificuldade de ensinar anestesia venosa. A falta de conhecimento teórico da farmacologia dos fármacos utilizados e a dificuldade em controlar o plano anestésico adequado foram apontadas como fatores pessoais limitantes às bombas de infusão, bem como o seu custo, abordados em diversos eventos como fatores ambientais ou estruturais limitantes ao uso de TIVA.

As mudanças de atitude frente a um novo aprendizado podem ser influenciadas pelo método de aprendizado e pelas características do local ou ambiente onde se pratica a técnica ${ }^{8}$.

O objetivo desse estudo foi determinar atitudes de anestesiologistas e médicos em especialização com relação à anestesia venosa total.

\section{MÉTODO}

O estudo foi aprovado pela Comissão de Ética Institucional. Para a concepção das amostras, foi construída uma lista de endereços eletrônicos de anestesiologistas portadores de Título Superior de Anestesiologia (TSA) $(n=760)$ e de médicos em especialização (ME) $(n=500)$, constantes do cadastro de sócios da Sociedade Brasileira de Anestesiologia (www.sba.com.br), aos quais foram atribuídos números aleatórios gerados eletronicamente (MS Excell, Microsoft Corp., Bellvue, WA). Considerando-se que a concordância ou discordância mínima aceitável para definir consenso em cada item do questionário $(\mathrm{P})$ igual a $70 \%$ dos respondentes, assumindo erro (e) de $5 \%$, o número de respostas aos questionários $(n)$ foi estimado em $84\left(n=P Q / e^{2}\right)$, onde $\mathrm{Q}=1-\mathrm{P}^{9}$. Assumindo uma taxa de respostas no pior cenário de $20 \%$ do total dos 1.260 potenciais participantes ${ }^{8}$, decidiu-se convidar 252 membros da lista ordenada de forma crescente de números aleatórios. O convite para a participação no estudo foi enviado por mensagem eletrônica que continha o vínculo para o endereço eletrônico do questionário. Os convidados da amostra inicial, que tiveram suas mensagens retornadas, foram substituídos por membros sucessivos da lista até ser atingido o número preestabelecido de participantes, procedimento que resultou em 150 anestesiologistas e 102 ME. A versão eletrônica do questionário foi criada com o programa MS FrontPage 2000 (Microsoft, Bellvue, WA) e alocada em um endereço eletrônico. A versão eletrônica continha o protocolo do estudo e o termo de consentimento pós-informação. O questionário consistia em 10 itens (Quadro I), medidos em escalas Likert de 5 pontos $(5=$ concordo completamente; 1 = discordo completamente). $\mathrm{O}$ questionário também continha campos para os seguintes dados demográficos, idade, sexo, tempo de prática de anestesia, categoria (anestesiologista ou ME) e freqüência de uso de TIVA (sempre/freqüentemente ou raramente/nunca). Duas mensagens-lembrete foram enviadas aos participantes a intervalos de duas semanas. A coleta de dados foi interrompida duas semanas após a última mensagem.

As respostas ao questionário foram submetidas à avaliação psicométrica através de análise de confiabilidade, pelo cálculo do coeficiente alfa de Cronbach, e análise fatorial pelo método de componentes principais. As respostas de níveis Likert 1 e 2 foram agrupadas como discordantes e as respostas de Likert 4 e 5 foram agrupadas como respostas concordantes e os respectivos porcentuais foram comparados por testes z para proporções. $O$ consenso dos participantes em cada item foi definido quando o valor de $p<5 \%$.

Quadro I - Questionário de Atitudes com Relação à Anestesia Venosa Total

1. Para realizar a TIVA são necessários conhecimentos mais profundos dos fármacos anestésicos, comparativamente com a anestesia inalatória

2. Se não dependesse de bombas de infusão, utilizaria com mais freqüência TIVA

3. Se o custo não fosse tão alto, utilizaria mais TIVA

4. Fico inseguro com a possibilidade de meus pacientes despertarem no intra-operatório, quando utilizo a TIVA

5. A qualidade do despertar pós-operatório estimula o uso da TIVA

6. A adição de monitores de consciência faria com que a freqüência de utilização de TIVA fosse maior

7. O futuro está em produzir fármacos de ação cada vez mais rápida para uso contínuo

8. É fácil aprender TIVA

9. Gostaria de utilizar mais TIVA

10. Gostaria de saber mais sobre TIVA

\section{RESULTADOS}

Foram obtidas 98 respostas (39\%). A tabela I descreve os dados demográficos da amostra.

O coeficiente alfa de Cronbach foi de 0,72 . O coeficiente de correlação ajustado médio entre os itens do questionário foi de 0,23. $O$ item 8 (é fácil aprender TIVA) mostrou baixa correlação com os demais itens $(r=0,09)$ e foi retirado do 
Tabela I - Dados Demográficos.

\begin{tabular}{lc}
\hline & $\mathrm{n}(\%)$ \\
\hline Sexo $(\mathrm{M} / \mathrm{F})$ & $83 / 15$ \\
Nível de treinamento $\left(\mathrm{ME}_{1} / \mathrm{ME}_{2} / \mathrm{ME}_{3}\right)$ & $3 / 10 / 8 / 77$ \\
$\begin{array}{c}\text { Tempo de exercício (anos) } \\
\quad<5 / 5-10 / 11-15 / 16-20 />20)\end{array}$ & $29 / 9 / 12 / 9 / 39$ \\
Usuários de TIVA (freqüentes/ocasionais) & $55 / 43$ \\
\hline
\end{tabular}

questionário. Uma estrutura de três fatores explicou $58 \%$ da variância das respostas aos itens. O fator 1 (atitudes positivas) teve um eingenvalue de 2,86 , foi responsável por $32 \%$ da variância e compreendeu os itens 5, 710 e 11. O fator 2 (preocupações) teve um eingenvalue de 1,18, foi responsável por $13 \%$ da variância e compreendeu os itens 1 , 4 e 6 . O fator 3 (limitações) teve um eingenvalue de 1,15, foi responsável por $13 \%$ da variância e compreendeu os itens 2 e 3. O questionário agrupado segundo a estrutura fatorial descrita, com os porcentuais de concordância ou discordância dos participantes com cada item é mostrado na Tabela II. Não foi obtido consenso entre os participantes com relação aos itens 1 (para realizar TIVA precisa-se de mais conhecimentos teóricos comparativamente com a anestesia inalatória; $p=0,88$ ), 2 (se não fosse preciso a utilização de bombas de infusão para fazer TIVA, provavelmente eu utilizaria com mais freqüência TIVA; $p=0,09$ ) e 3 (se os custos não fossem tão elevados, eu utilizaria TIVA com mais freqüência; $p=0,06)$.

Tabela II - Respostas ao Questionário.

\begin{tabular}{|c|c|c|}
\hline Fator - Item & Concordo & Discordo \\
\hline 5. A qualidade do despertar pós-operatório me estimula a usar TIVA & $86(88)^{*}$ & $8(8)$ \\
\hline 7. O futuro está em produzir fármacos com início de ação e pronta recuperação para uso contínuo & $88(90)^{*}$ & $5(5)$ \\
\hline 8. Gostaria de realizar TIVA com mais freqüência & $72(73)^{*}$ & $21(21)$ \\
\hline $\begin{array}{l}\text { 1. Para realizar TIVA são necessários conhecimentos mais profundos das drogas anestésicas, } \\
\text { comparativamente com a anestesia inalatória }\end{array}$ & $48(49)$ & $47(48)$ \\
\hline $\begin{array}{l}\text { 4. Fico inseguro com a possibilidade de meus pacientes despertarem no perioperatório, } \\
\text { quando utilizo TIVA }\end{array}$ & $20(20)^{*}$ & $75(77)^{*}$ \\
\hline 2. Se não dependesse de bombas de infusão, utilizaria com mais freqüência TIVA & $52(53)$ & $40(41)$ \\
\hline 3. Se o custo não fosse tão alto, utilizaria mais TIVA & $52(53)$ & $39(40)$ \\
\hline
\end{tabular}

Dados apresentados em n (\%)

${ }^{*} p<0,05$

\section{DISCUSSÃO}

A proposta deste estudo foi medir as atitudes de anestesiologistas e médicos em especialização com relação à anestesia venosa total no Brasil, por meio de um instrumento especialmente desenvolvido, cujas características psicométricas se demonstrassem confiáveis para a medida do constructo a que se propunha. O coeficiente alfa de Cronbach encontrado $(0,72)$ mostrou que o instrumento possui confiabilidade adequada, servindo, portanto, como medida de atitudes com relação à anestesia venosa ${ }^{10}$. 0 questionário também mostrou clara estrutura fatorial que refletiu os objetivos dos itens construídos (entusiasmo com a técnica, temores e preocupações em sua aplicação e limitações ao seu uso, impostas por fatores do ambiente de trabalho).

Os dados foram coletados eletronicamente, via Internet. As pesquisas de opinião aplicadas a ciências da saúde permitiram acesso rápido a um grande número de indivíduos, rápida coleta de dados e considerável economia de recursos. Contudo, tanto a validade externa dos resultados quanto as taxas de resposta poderiam ser prejudicadas por diversas fontes de erro. Os erros de amostragem podem ocorrer, quando somente uma proporção da população-alvo é incluí- 
da; erros de abrangência podem ocorrer quando algumas unidades da população-alvo são excluídas, ou desproporcionalmente incluídas; erros de medida podem ocorrer como conseqüência do formato da pesquisa, características do programa de acesso à Internet, variáveis situacionais e características dos respondentes. Os fatores que influenciam nas taxas de resposta incluem a natureza sensível das questões, a falta de disposição em participar, a falta de interesse no objeto da pesquisa e a falta de confiança na garantia de confidencialidade das respostas. $\mathrm{O}$ uso difundido de programas antianúncios por usuários e provedores de acesso também pode bloquear o acesso das mensagens de convite feitas eletronicamente. Por essas razões, baixas taxas de resposta devem ser esperadas ${ }^{11-13}$. Para tentar diminuir esses problemas, delimitou-se a população-alvo a um grupo de indivíduos com interesses comuns (nesse caso, os membros da Sociedade Brasileira de Anestesiologia que de forma voluntária disponibilizaram seus endereços eletrônicos), testou-se previamente o questionário para conferir a clareza dos itens, garantiu-se o anonimato dos participantes, foram emitidas mensagens-lembrete $e$ realizou-se o cálculo do tamanho da amostra previamen$t^{9,13}$. Entre os fatores positivos com relação à TIVA foram apontadas a qualidade de despertar e confiança no futuro desenvolvimento de fármacos cada vez mais adequados, disposição em aprender e realizar técnicas de anestesia venosa total. De fato, a linha de pesquisa da maioria das empresas aponta para dois importantes aspectos: o desenvolvimento de fármacos de ação rápida e com mínima interferência no organismo humano ${ }^{14}$.

Em contraposição à pesquisa de Wright e Dundee ${ }^{3}$, os participantes desse estudo demonstraram pouca preocupação com a possibilidade de despertar intra-operatório, embora concordando que a maior disponibilidade de monitores de consciência poderia contribuir para o uso mais amplo da anestesia venosa total. De fato, tem sido demonstrado que após o advento desses equipamentos a incidência de despertar no perioperatório diminuiu em torno de $77 \%{ }^{5}$.

Quando o estudo de Wright e Dundee ${ }^{3}$ foi publicado, os anestésicos venosos possuíam características farmacocinéticas muito diferentes dos atuais, com vidas-média de eliminação prolongadas, o que não os credenciava para infusões contínuas. Os fármacos utilizados atualmente possuem vidas-média de eliminação muito mais curtas, sendo possível a utilização de infusões-alvo-controladas, permitindo rápida indução e emergência da anestesia. O perfil farmacocinético dos fármacos utilizados em infusão venosa contínua tem contribuído para a difusão da técnica, bem como para a obtenção de maiores escores de segurança com a sua utilização. Esses avanços podem explicar a atitude positiva dos participantes desse estudo com relação à qualidade do despertar proporcionado pelas técnicas atuais de anestesia venosa total.

Porcentagens similares de participantes apontaram a dependência das técnicas de anestesia venosa total na dispo- nibilidade de bombas de infusão e o alto custo da TIVA como fatores limitantes ou não, demonstrando falta de consenso sobre os aspectos fármaco-econômicos da anestesia venosa total. O custo de qualquer técnica de anestesia utilizada atualmente, seja anestesia balanceada ou venosa total, não ultrapassa a $6 \%$ dos custos totais de um procedimento cirúrgico, situando-se entre $1 \%$ e $4 \%$ na maioria dos procedimentos ${ }^{15,16}$. A aplicação do questionário via Internet mostrou-se uma ferramenta de fácil obtenção de respostas, uma ferramenta útil e fidedigna para a medida de atitudes com relação à anestesia venosa. $O$ questionário identificou áreas específicas sobre as quais não há consenso de opiniões entre anestesiologistas, que podem ser objeto de ensino e treinamento.

Concluiu-se que as atitudes de anestesiologistas e ME com relação à TIVA são predominantemente positivas; que a qualidade de despertar foi identificada como um fator estimulante para a escolha da técnica; que não há consenso quanto à preocupação com os custos ou com a disponibilidade de equipamentos especiais para a sua realização, sugerindo que os seus aspectos fármaco-econômicos precisam ser mais difundidos; que embora não haja preocupação com despertar perioperatório, a maioria dos anestesiologistas concorda que se monitores de consciência intra-operatória fossem mais disponíveis, a TIVA seria mais amplamente utilizada; que há interesse no aprendizado, bem como há interesse na realização mais freqüente da técnica, o que sugere que existe espaço para cursos, workshops e outras ferramentas instrucionais na área de anestesia venosa.

\section{Current Attitude of Anesthesiologists and Anesthesiology Residents Regarding Total Intravenous Anesthesia}

Fernando Squeff Nora, TSA, M.D.; Marcos Aguzzoli, TSA, M.D.; Getúlio Rodrigues de Oliveira Filho, TSA, M.D.

\section{INTRODUCTION}

Among the techniques of administering general anesthesia, balanced anesthesia, commonly related to the use of inhalational and intravenous drugs, has dominated the world for several years ${ }^{1}$. Currently, balanced anesthesia has divided the anesthesiologists' preferences with total intravenous anesthesia (TIVA) ${ }^{2}$. Although it is still underused, in a few European countries TIVA is already the technique of choice ${ }^{2}$.

Wright and Dundee ${ }^{3}$ published a study done in the United Kingdom evaluating the attitude regarding the use of TIVA, more specifically regarding the acceptance of the technique. The main causes of dissatisfaction were the infusion pumps available, costs, the absence of adequate and safe intravenous drugs, the difficulty to determine the anesthetic plane, and the lack of information and training. 
Currently one can mention, among others, two changes that were responsible for the increase in the use of TIVA, namely the understanding and the development of pharmacokinetics models for new intravenous drugs, which made it possible the continual infusion of these drugs ${ }^{4}$ and the availability of consciousness monitors for peri-operatory use $\mathrm{e}^{2,5,6}$.

Nora et al. ${ }^{7}$, using pre and post-tests applied in TIVA courses, identified some factors responsible for the difficulty to teach intravenous anesthesia. The lack of theoretical knowledge on the pharmacology of the drugs used and the difficulty to control the adequate anesthetic plane were indicated as limiting personal factors, while infusion pumps and its costs are mentioned in several events as limiting environmental or structural factors to the use of TIVA.

The changes in the attitude regarding learning new tasks can be influenced by the learning method and by the characteristics of the place or environment where the technique is practiced $^{8}$.

The objective of this study was to determine the attitude of anesthesiologists and anesthesiology residents residents regarding total intravenous anesthesia.

\section{METHODS}

The study was approved by the Institutional Ethics Committee. To select the population, we made a list of electronic addresses of anesthesiologists with the Título Superior de Anestesiologia (TSA - Certificate of Anesthesiology) ( $n=$ $760)$ and of anesthesiology residents $(A R)(n=500)$ belonging to the roster of the Brazilian Society of Anesthesiology (www.sba.com.br). They were assigned numbers randomly generated electronically (MS Excell, Microsoft Corp., Bellvue, WA). Considering that the minimum acceptable concordance and disagreement to define consensus in each item of the questionnaire $(P)$ is $70 \%$ of those who answered it, and assuming an error (e) of $5 \%$, the number of answers to the questionnaires $(n)$ was estimated in $84\left(n=P Q / e^{2}\right)$, where $\mathrm{Q}=1-\mathrm{P}^{9}$. Assuming that, in the worst-case scenario, only $20 \%$ of the total potential of 1,260 participants would answer the questionnaire ${ }^{8}$, we decided to invite the first 252 members of the list of randomly assigned numbers organized in crescent order. The invitation to participate in the study was made by an e-mail containing the link for the electronic questionnaire. The messages from the initial invitation that were returned were substituted successively by other members of the list until we reached the pre-established number of participants, resulting in the participation of 150 anesthesiologists and $102 \mathrm{AR}$. The electronic version of the questionnaire was created using the MS FrontPage 2000 (Microsoft, Bellvue, WA) and placed it in a website. The electronic version contained the study protocol and the consent form. The questionnaire contained 10 items (Chart I) measured in a 5-point Likert scale (5 = strongly agree; 1 = strongly disagree). It also contained places for the following demographic data: age, gender, length of time practicing Anesthe-
Chart I - Questionnaire on the Attitude Regarding Total Intravenous Anesthesia

1. To administer TIVA it is necessary deeper knowledge about the anesthetics than for inhaled anesthesia.

2. I would use TIVA more often if it did not require infusion pumps.

3. I would use TIVA more often if the costs were not so high.

4. When I use TIVA, I am insecure about the possibility that my patients might awaken in the operative period.

5. The quality of the postoperative awakening encourages the use of TIVA.

6. The availability of consciousness monitors would increase the use of TIVA.

7. The future relies on the development of drugs with increasingly faster onset of action for continuous administration.

8. It is easy to learn to administer TIVA.

9. I would like to use TIVA more often.

10. I would like to have more information on TIVA.

siology, category (anesthesiologist or AR), and how often TIVA is used (always/frequently or rarely/never). Two reminder messages were sent to the participants at a 2-week interval. Data collection was interrupted two weeks after the last message.

The answers to the questionnaire were submitted to a psychometric assessment by reliability analysis, by the calculus of the Cronbach alpha coefficient, and factorial analysis by the principal components method. Answers on Likert levels 1 and 2 were grouped as disagreement and answers on Likert levels 4 and 5 were grouped as agreement and the respective percentiles were compared by $z$ test for proportions. The consensus of the participants on each item was defined when $p<5 \%$.

\section{RESULTS}

We obtained 98 answers (39\%) to the questionnaire. Table I shows the demographics data of the sample.

The alpha Cronbach coefficient was 0.72 . The adjusted mean correlation coefficient among the items in the

Table I - Demographics Data

\begin{tabular}{lc}
\hline & $n(\%)$ \\
\hline Gender $(\mathrm{M} / \mathrm{F})$ & $83 / 15$ \\
Level of training $\left(\mathrm{AR}_{1} / \mathrm{AR}_{2} / \mathrm{AR}_{3}\right.$ & $3 / 10 / 8 / 77$ \\
$\begin{array}{c}\text { Length of time in practice (years) } \\
(<5 / 5-10 / 11-15 / 16-20 />20\end{array}$ & $29 / 9 / 12 / 9 / 39$ \\
TIVA users (frequent/occasional) & $55 / 43$ \\
\hline
\end{tabular}


questionnaire was 0.23 . Item 8 (it is easy to learn TIVA) showed a low correlation with the other items $(r=0.09)$ and was taken out of the questionnaire. A structure of three factors explained the $58 \%$ variance in the answers to the items. Factor 1 (positive attitudes) had an eigenvalue of 2.86 , being responsible for $32 \%$ of the variance and involved items 5, 7, 10, and 11. Factor 2 (worries) had an eigenvalue of 1.18 , being responsible for $13 \%$ of the variance and involved items 1, 4, and 6. Factor 3 (limitations) had an eigenvalue of 1.15 , being responsible for $13 \%$ of the variance and involved items 2 and 3 . Table II shows the questionnaire formed according to the factorial structure described above, with the percentage of participants that agree and disagree with each item. There was no consensus among the participants regarding items 1 (to perform TIVA it is necessary to have more theoretical knowledge than for inhalation anesthesia; $p=0.88$ ), 2 (I would probably use TIVA more often if it did not require the use of infusion pumps; $p=0.09$ ), and 3 (I would use TIVA more often if the costs were not so high; $p=0.06)$.

Table II - Answers to the Questionnaire

\begin{tabular}{|c|c|c|}
\hline Factor - Item & Concordance & Discordance \\
\hline 5. The quality of the postoperative awakening encourages the use of TIVA & $86(88)^{*}$ & $8(8)$ \\
\hline $\begin{array}{l}\text { 7. The future relies on the development of drugs with increasingly faster onse } \\
\text { continuous administration }\end{array}$ & $88(90)^{*}$ & $5(5)$ \\
\hline 8. I would like to use TIVA more often & $72(73)^{*}$ & $21(21)$ \\
\hline \multicolumn{3}{|l|}{ Factor 2 - Concerns } \\
\hline $\begin{array}{l}\text { 1. To administer TIVA it is necessary deeper knowledge about the anesthetics } \\
\text { inhalational anesthesia }\end{array}$ & $48(49)$ & $47(48)$ \\
\hline $\begin{array}{l}\text { 4. When I use TIVA, I am insecure about the possibility that my patients might a } \\
\text { the operative period }\end{array}$ & $20(20)^{*}$ & $75(77)^{*}$ \\
\hline 2. I would use TIVA more often if it did not require infusion pumps & $52(53)$ & $40(41)$ \\
\hline 3. I would use TIVA more often if the costs were not so high & $52(53)$ & $39(40)$ \\
\hline
\end{tabular}

Data presented in numbers (\%)

${ }^{*} \mathrm{p}<0.05$

\section{DISCUSSION}

The aim of this study was to measure the attitude of Brazilian anesthesiologists and anesthesiology residents regarding total intravenous anesthesia using a specially designed tool with reliable psychometric characteristics. The Cronbach alpha coefficient found (0.72) showed that the questionnaire had adequate reliability, therefore being useful to measure the attitude regarding intravenous anesthesia ${ }^{10}$. The questionnaire also showed a clear factorial structure that reflected the objectives of the items analyzed (enthusiasm with the technique, fears and concerns regarding its administration, and the limitations to its use due the characteristics of the working environment).

The data was collected through the Internet. Polls applied to health sciences allowed quick access to a large number of individuals, fast data gathering, and a remarkable economy of resources. However, both the external validity of the results and the answer rate could be hindered by several sources of error. Sampling errors might occur when just part of the target population is included; there might be enclosure errors when some units of the target population are excluded or disproportionably included; measurement errors may occur as a consequence of the structure of the research, characteristics of the Internet access program, situational variables, and characteristics of those who answered the questionnaire. The factors that influenced the response rates include the sensitive nature of the questions, lack of disposition to participate; lack of interest on the subject of the study; and lack of trust in the guarantee of confidentiality. The widespread use of anti-pop up programs by users and access providers can also block the access to invitation messages sent by e-mail. For those reasons, one must expect a low rate of answers ${ }^{11-13}$. To try to decrease those problems, the target population was limited to a group of individuals with common interests (in this case, the members of the Brazilian 
Society of Anesthesiology who made their e-mail available spontaneously), the questionnaire was tested previously to confirm the clarity of the items, the anonymity of the participants was guaranteed, reminder messages were sent, and we calculated previously the size of the sample necessary ${ }^{9,13}$. Among the positive factors regarding TIVA was the quality of the awakening, the trust in the future development of increasingly more adequate drugs, and the willingness to learn and perform the techniques of total intravenous anesthesia. In fact, the line of research of most companies indicates two aspects: the development of fast acting drugs and drugs that interfere as little as possible in the human body ${ }^{14}$. Contrary to Wright and Dundee's research ${ }^{3}$, those who participated in our study demonstrated little concern with the possibility of intra-surgical awakening, but they agreed that the availability of consciousness monitors could contribute to the widespread use of total intravenous anesthesia. In fact, it has been shown that, after the institution of this equipment, the incidence of intraoperative awakening has had a reduction of approximately $77 \%$.

When Wright and Dundee's ${ }^{3}$ study was published, intravenous anesthetics had very different pharmacokinetics than the ones available nowadays, with long elimination half-lives, therefore, they were not suitable for continuous infusion. The half-life of the drugs used currently is much shorter and can be used in target-controlled infusions, allowing for fast induction and awakening from the anesthesia. The pharmacokinetics profile of the drugs used for continuous intravenous infusion has contributed for the diffusion of the technique, as well as for higher safety scores. These developments can explain the positive attitude of those participating in this study regarding the quality of the awakening of the current techniques of total intravenous anesthesia. The number of participants that mentioned the need for infusion pumps and the high cost of TIVA as limiting factors for its use is similar to those who disagree, showing a lack of consensus about the pharmacologic-economic aspects of total intravenous anesthesia. The costs of any anesthetic technique used nowadays, whether it is balanced or total intravenous anesthesia, do not exceed $6 \%$ of the total cost of a surgical procedure, being between $1 \%$ and $4 \%$ in the majority of the procedures ${ }^{15,16}$. The use of a questionnaire through the Internet showed to be a tool that facilitated the acquisition of answers, a useful and reliable tool to assess the attitude regarding intravenous anesthesia. The questionnaire identified specific areas in which there was no consensus among the anesthesiologists, which can be the objective of teaching and training.

We concluded that the attitude of anesthesiologists and residents regarding TIVA are predominantly positive; that the quality of the awakening was identified as a factor that stimulates the choice of the technique; that there is no con- sensus regarding concerns about the costs or about the availability of special equipment for its administration, suggesting that its pharmacologic-economic aspects have to be more disseminated; that, even though there are no concerns about the intraoperative awakening, the majority of anesthesiologists agree that, if consciousness monitors were easier to obtain, TIVA would be used more often; that there is interest in learning the technique as well as using the technique more often, suggesting that there is a place for courses, workshops, and other institutional tools in the field of intravenous anesthesia.

\section{REFERÊNCIAS - REFERENCES}

01. Nora FS, Fortis EAF - Influência dos fármacos utilizados na sedação, na indução e manutenção quanto a recuperação da anestesia. Rev Bras Anestesiol, 2000;50:141-148.

02. Passot S, Servin F, Allary R et al - Target-controlled versus manually-controlled infusion of propofol for direct laryngoscopy and bronchoscopy. Anesth Analg, 2002;94:1212-1216.

03. Wright PJ, Dundee JW - Attitudes to intravenous infusion anaesthesia. Anaesthesia, 1982;37:1209-1213.

04. Hughes MA, Glass PS, Jacobs JR - Context-sensitive half-time in multicompartment pharmacokinetic models for intravenous anesthetic drugs. Anesthesiology, 1992;76:334-341.

05. Ekman A, Lindholm ML, Lennmarken $C$ et al - Reduction in the incidence of awareness using BIS monitoring. Acta Anaesthesiol Scand, 2004;48:20-26.

06. Struys MM, Jensen EW, Smith W et al - Performance of the ARXderived auditory evoked potential index as an indicator of anesthetic depth: a comparison with bispectral index and hemodynamic measures during propofol administration. Anesthesiology, 2002;96:803-816.

07. Nora FS, Aguzzoli M, Fortis EAF - Training in intravenous anaesthesia - pre and post course testing improves teaching techniques in future workshops. Annual Scientific Meeting of the UK Society for intravenous anesthesia. Oxford, European Society of Intravenous Anaesthesia, 2003.

08. Oliveira Filho GR - Rotinas de cuidados pós-anestésicos de anestesiologistas brasileiros. Rev Bras Anestesiol, 2003; 53:518-534.

09. Mattar FN - Pesquisa de marketing. São Paulo, Editora Atlas, 1999.

10. Cronbach $L-$ Coefficient alpha and the internal structure of tests. Psychometrika, 1951;16:297-334.

11. Braithwaite D, Emery J, De Lusignan S et al - Using the Internet to conduct surveys of health professionals: a valid alternative? Fam Pract, 2003;20:545-551.

12. Ness TJ, Jones L, Smith $H$ - Use of compounded topical analgesics - results of an Internet survey. Reg Anesth Pain Med, 2002;27:309-312.

13. Yetter Read $\mathrm{C}-$ Conducting a client-focused survey using e-mail. Comput Inform Nurs, 2004;22:83-89.

14. Kilpatrick GJ, Tilbrook GS - Improved Agents for Hypnosis and Sedation, $8^{\text {th }}$ Ed, Vienna, EuroSiva, 2005.

15. Churnside RJ, Glendenning GA, Thwaites RMA et al - Resource use in operative surgery: UK general anaesthetic costs in perspective. Br J Med Economics, 1996;10:83-98.

16. Rowe WL - Economics and anaesthesia. Anaesthesia, 1998; 53:782-788. 


\section{RESUMEN}

Nora FS, Aguzzoli M, Oliveira Filho GR - Actitudes Actuales de Anestesiólogos y Médicos en Especialización con Relación a la Anestesia Venosa Total.

JUSTIFICATIVA Y OBJETIVOS: Antiguamente, tiempo, costes, informaciones, capacitación y evaluación de la profundidad de la anestesia limitaban la aceptación de la anestesia venosa total (TIVA). El objetivo de este estudio fue el de determinar las actitudes de anestesiólogos y médicos en especialización con relación a la anestesia venosa total.

MÉTODO: Un cuestionario fue enviado a 150 anestesiólogos y 102 residentes. La concordancia $(C)$ y discordancia $(D)$ en cada ítem se compararon por pruebas $z$ (consenso, si $p<0,05$ ).

RESULTADOS: Hubo 98 respuestas. Los datos representaron números de respuestas por categoría. La mayoría de los participan- tes concordó en que la calidad del despertar estimula el uso de TIVA (C/D = 86/8; $p<0,05)$; que el futuro reside en el desarrollo de fármacos con un rápido inicio de acción y una rápida recuperación $(C / D=88 / 5 ; p<0,05)$; que les gustarían utilizar TIVA con más frecuencia $(C / D=72 / 21 ; p<0,05)$ y saber más sobre TIVA $(C / D=$ $77 / 14 ; p<0,05)$. No hubo consenso sobre el nivel de conocimiento para realizarla, comparada con la anestesia de inhalación $(C / D=$ 48/47); la mayoría no expresó preocupación con la conciencia intraoperatória $(C / D=20 / 77 ; p<0,05)$, pero concordó en que la disponibilidad de monitores de conciencia, aumentaría la utilización de TIVA $(C / D=64 / 25 ; p<0,05)$. No hubo consenso sobre la necesidad de bombas de infusión $(C / D=52 / 40)$ y costes $(C / D=52 / 39)$ limitan su uso.

CONCLUSIONES: Las actitudes con relación a la TIVA fueron predominantemente positivas. No hubo consenso sobre las contribuciones del nivel de conocimiento, de los dispositivos de infusión $y$ de los costes para el uso de TIVA. 